\title{
Asesmen Aspek Perkembangan Nilai Agama dan Moral Menggunakan Teknik Penilaian Penugasan (Unjuk Kerja) di TK Al-Fadillah Kelompok (B) Usia 5-6 Tahun Sleman DIY
}

\author{
Sri Wahyuni \\ Universitas Islam Negeri Sunan Kalijaga Yogyakarta \\ sri.wahyuni02feb@gmail.com
}

\begin{abstract}
This research is a direct research in the field using a descriptive qualitativ approach. This study aims to (1) describe the implementation of religious and moral values in Al-Fadlillah Kindergarten, Sleman, DIY (2) Describe assesment techniques in the form of assignments (performance) and asessment instrument used in Al-Fadillab Kindergarten, Sleman, DIY (3) describes the follow-up carried out by the teacher after the assesment took place. Data collection is done by observation, interview, and documentation studies . data were analyzed using Miles and Hubberman techniques trough the process of data reduction, data display, and conclusion drawing. The results of the data analysis show that assessing aspect of the development of religious and moral values trough the performance evaluation techniques carried out every day for example activities are children praying, greeting and sharing, each week, an example of activity is practicing worship movements, reciting short prayers, etc., assignment techniques (performance) in seeing aspects of the development of religious and moral values in Al- Fadlillah Kindergarten, Sleman, DIY teachers use assesment instrument in the form of checks and portofolios.
\end{abstract}

Keywords: Assessment, aspects religious and Moral V alues, Assignments (Performance).

\begin{abstract}
Abstrak
Penelitian ini merupakan penelitian langsung di lapangan dengan menggunakan pendekatan kualitatif deskriptif. Penelitian ini bertujuan untuk (1) mendeskripsikan implementasi asesmen aspek perkembangan nilai agama dan moral di TK Al-Fadlillah, Sleman, DIY (2) Mendeskripsikan teknik penilaian berupa penugasan (unjuk kerja) dan instrumen penilaian yang digunakan di TK Al-Fadlillah, Sleman, DIY (3) mendeskripsikan tindak lanjut yang dilakukan guru setelah penilaian berlangsung. Pengumpulan data dilakukan dengan teknik observasi, wawancara, dan studi dokumentasi. Data dianalisis menggunakan teknik Miles dan Hubberman melalui proses reduksi data, display data, dan penarikan kesimpulan. Hasil dari analisis data yang dilakukan menunjukkan
\end{abstract}


bahwa asesmen aspek perkembangan nilai agama dan moral melalui melalui teknik penilaian unjuk kerja dilakukan setiap hari contoh kegiatannya adalah anak berdoa, memberi salam, dan berbagi, setiap minggu contoh kegiatannya adalah mempraktekkan gerakan beribadah, membacakan doa-doa pendek, dan lain sebagainya, setiap bulan, dan setiap semester. Untuk penilaian menggunakan teknik penugasan (unjuk kerja) dalam melihat aspek perkembangan nilai agama dan moral di TK Al-Fadlillah, Sleman, DIY guru menggunakan instrumen penilaian berupa ceklis dan portofolio.

Kata Kunci: Asesmen, Aspek Nilai Agama dan Moral, Penugasan (Unjuk Kerja).

\section{PENDAHULUAN}

Setiap orang yang memliki moral akan mampu membedakan mana hal yang baik dan mana yang tidak baik. Penentuan baik dan buruknya suatu hal bukan paksaan yang diterima dari pihak luar, melainkan berasal dari kesadaran sebagai hasil eksistensinya sebagai manusia. Untuk menghasilkan pribadi yang memiliki moral yang baik, tidak dapat dilakukan dalam waktu yang singkat, tetapi harus melalui sebuah proses yang panjang dan dimulai sedini mungkin. Proses pembentukan karakter seseorang yang memiliki nilai agama dan moral yang baik harus dimulai dari usia dini, dimana pada usia dini 0-6 tahun adalah masa yang tepat dalam menanamkan nilai-nilai di dalam diri anak, nilai-nilai yang ajarkan akan tertaman dalam diri anak dan menjadi karakter anak kedepannya ketika sudah dewasa.

Pada usia dini atau yang sering disebut dengan masa keemasan (Golden Age) anak mengalami perkembangan yang sangat pesat dan merupakan penentu bagaimaan masa depan anak kedepannya (Sulastri, 2014, p. 3). Jika terjadi kesalahan atau orang tua, guru dan orang disekitar anak mengabaikan masa ini dalam mendidik anak maka dampak negatif yang ditimbulkan bukan hanya pada masa anak-anak saja tetapi akan berlangsung pada masa-masa selanjutnya dan melekat atau menjadi karakter anak itu sendiri.

Sepanjang tahun 2011 hingga 2017 terdapat 9.266 kasus amoral yang didalamnya anak bukan hanya sebagai korban melainkan anak merupakan pelaku dari kasus-kasus tersebut. Dari tahun ke tahun, jumlah paling banyak yaitu tahun 2014. Dimana kasus ABH mencapai jumlah 2.208. Jumlah anak sebagai pelaku dari kasus-kasus tersebut tak kalah tinggi, tercatat pada tahun 2017 anak sebagai pelaku kekerasan seksual sebanyak 116 kasus, sedangkan anak sebagai korban sebanyak 134 kasus. KPAI juga menangani 1.885 kasus pada semester pertama 2018. Dari angka itu, anak berhadapan dengan hukum (ABH) seperti jadi pelaku narkoba, mencuri, hingga asusila menjadi kasus yang paling banyak. Data KPAI menyebutkan ada 504 kasus $\mathrm{ABH}$, diposisi kedua ada kasus keluarga dan pengasuhan alternatif atau anak 
yang orang tuanya bercerai, posisi ketiga, pornografi dan cyber crime dengan 255 kasus (detiknews.com, 23 Juli 2018). Kasus-kasus yang terjadi di atas memang tidak dilakukan oleh anak usia dini tetapi pada usia selanjutnya. Seperti yang kita ketahui pentingnya penanaman nilai-nilai dalam diri anak ketika berada pada masa golden age dikarenakan akan menjadi karakter seorang anak kedepannya, gagalnya penanaman nilai pada anak usia dini akan berdampak pada masa depan anak kedepannya. Ada banyak faktor yang menyebabkan terjadinya kasus di atas, salah satunya adalah gagalnya pendidik dalam menanamkan nilai moral dan agama ke dalam diri anak sehingga terjadinya hal-hal yang keluar dari nilai agama dan moral.

Pada sebuah lembaga PAUD ada enam aspek yang harus dikembangkan dalam diri anak, salah satu dari aspek tersebut adalah nilai agama dan moral. Pendidikan nilai agama dan moral erat kaitannya dengan budi pekerti seorang anak, sikap sopan santun, kemauan melaksanakan ajaran agama dalam kehidupan sehari-hari (Lestariningrum,2014, p. 203). Kemudian dapat dipahami bahwa keberadaan pendidikaan nilai agama dan moral pada program PAUD merupakan pondasi yang kokoh dan sangat penting keberadaanya, jika hal ini ditanamkan pada setiap insan dari usia dini maka hal ini akan terpatri dengan baik dan mencegah anak melakukan hal-hal yang bersikap amoral, hal tersebut akan menjadi awal yang baik bagi pendidikan anak bangsa untuk menjalani pendidikan selanjutnya (Asmar, 2014, p. 44).

Asesmen atau penilaian merupakan salah satu tugas pokok dan penting yang harus dilakukan oleh guru PAUD, selain melakukan perencanaan dan pelaksanaan pembelajaran. Asesmen menjadi sangat penting dilakukan karena melalui hasil asesmen guru dapat mengetahui dan mendeskripsikan tingkap pencapaian perkembangan anak, termasuk di dalamnya perkembangan nilai agama dan moral pada anak. Dari penilaian tersebut dapat diketahui dan ditetapkan aspek-aspek perkembangan yang telah dicapai dan yang belum di capai oleh anak (Yus, 2011, p. 40).

Asesmen merupakan suatu proses untuk pengumpulan, pelaporan, dan penggunaan informasi mengenai proses dan hasil pembelajaran siswa dengan menerapkan prinsip-prinsip penilaian, akuran, dan mengidentifikasi pencapaian kompetensi belajar anak. Dengan adanya hasil asesmen, guru dan orang tua tahu bagaimana proses perkembangan serta pencapaian hasil belajar yang dapat dicapai oleh anak dalam hal kemampuan kognitif, sikap, dan kepribadian (Zurqoni, 2013, p. 187). 
Sesuai dengan penelitian sebelumnya yang dilakukan oleh Khoirul Bariyyah dengan judul penelitian "Asesmen Perkembangan Moral Agama AUD: Studi di TK ABA Pajangan Berbah Sleman", yang mengatakan bahwa dalam pembelajaran di PAUD asesmen tidak digunakan untuk menentukan hasil seorang anak dalam mengikuti pembelajaran, tetapi digunakan untuk mengukur tingkat pencapaian perkembangan pada setiap anak. Maka dari itu, proses asesmen anak di PAUD menggunakan pendekatan otentik. Asesmen otentik merupakan asesmen proses dan hasil belajar untuk mengukur tingkat pencapaian kompetensi sikap (spiritual dan sosial), pengetahuan dan keterampilan berdasarkan fakta sesungguhnya. Sehingga ketika terjadi penyimpangan atau gangguan perkembangan, guru dan orang tua segera tau dan mengerti cara menanggulanginya. Di TK Al-Fadlillah Sleman, Yogyakarta sendiri telah menggunakan penilaian otentik dalam melakukan asesmen, salah satu teknik penilaian yang digunakan adalah penugasan berupa unjuk kerja, dengan demikian guru dapat melihat proses anak bukan hanya hasil akhir yang dicapai oleh anak.

Cara untuk melakukan asesmen sangat beragam, mulai dari asesmen informal sampai dengan asesmen formal. Asesmen formal biasa berbentuk tes terstandar. Namun pada jenjang PAUD asesmen informal lebih disarankan dari pada penggunaan tesstandar. Hasil asesmen tersebut selanjutnya dapat digunakan sebagai dasar untuk membuat perencanaan dalam memberikan stimulasi yang lebih kompleks, namun tetap sesuai dengan kebutuhan dan tahap perkembangan anak (Fridani, 2008, p. 11).

Berdasarkan pemaparan di atas, dapat dilihat betapa pentingnya asesmen dilakukan untuk melihat bagaimana proses dan pencapaian perkembangan anak, terutama mengenai aspek nilai agama dan moral yang memberikan dampak yang sangat besar dan berlanjut sampai anak dewasa. Maka dari itu peneliti tertarik untuk melakukan penelitian tentang asesmen aspek perkembangan nilai agama dan moral menggunakan teknik penilaian penugasan (unjuk kerja) di TK Al-Fadlillah kelompok B usia 5-6 tahun sleman, DIY.

\section{METODE}

Penelitian ini merupakan penelitian lapangan dengan menggunakan pendekatan kualitatif deskriptif. Penelitian ini dilakukan di TK Al-Fadlilah Mambilegi Kidul, Maguwoharjo, Depok, Sleman, DIY yang lokasinya bersampingan dengan mesjid AlFadlilah. Proses pengumpulan data menggunakan teknik observasi partisipatif (participat observation), wawancara secara mendalam (indepth interview), dan studi dokumentasi 
(documentation study). Peneliti menggunakan teknik purposive sampling untuk menentukan sumber data dalam penelitian ini. purposive sampling merupakan teknik pengambilan sumber data dengan pertimbangan tertentu. Misalnya, orang yang dianggap paling tahu dan dapat memberikan informasi yang diharapkan atau seorang penguasa yang dapat memudahkan peneliti untuk menjelajahi objek/situasi sosial yang diteliti (Sugiyono, 2014, p. 85). Adapun sumber data dalam penelitian ini adalah salah satu guru dan kepala sekolah TK Al-Fadlilah Sleman, Yogyakarta. Selain itu sumber data dari penelitian ini juga berasal dari dokumen seperti lembar penilaian siswa dan buku rapor siswa. Mengingat penelitian ini adalah penelitian dengan menggunakan pendekatan kualitatif, maka instrumen pertama dari penelitian ini adalah peneliti sendiri, peneliti yang mendatangi lokasi, peneliti juga yang melakukan observasi dan dokumentasi, memilih informan dan melakukan wawancara dengan informan. Semua data yang telah diperoleh kemudian dianalisis menggunakan teknik analisis data kualitatif model Miles dan Hubberman yang meliputi tiga tahap yakni datareduction, data display, dan conclussion drawing/veryfication (Emzir, 2011, p. 129-131).

\section{PEMBAHASAN}

Salah satu aspek perkembangan anak usia dini pada kurikulum 2013 adalah unsurunsur nilai agama dan moral selain lima aspake perkembangan yang lain (Permendikbut No 137 Tahun 2014, p. 5). Di dalam penilitian Khoirul Bariyyah dengan judul penelitian “Asesmen Perkembangan Moral Agama AUD: Studi di TK ABA Pajangan Berbah

Sleman", mengemukakan bahwa nilai teridiri dari dua yaitu nilai nurani dan nilai memberi. Sementara nilai agama adalah nilai-nilai yang berkembang berdasarkan ajaran agama (Zurqoni, 2013, p. 47).

Menurut Lorens, kata moral berasal dari bahasa latin, yaitu dari kata mos (adat istiadat, kebiasaan, tingkah laku, kelakuan), atau mores (adat istiadat, kelakuan, tabiat, watak, akhlak, cara hidup). Helden dan Richards berpendapat moral adalah suatu kepekaan dalam pikiran, perasaan, dan tindakan dibandingkan dengan tindakan lain yang tidak hanya berupa kepekaan terhadap prinsip dan aturan. Selanjutnya, Atkinson mengemukakan moral merupakan pandangan tentang baik dan buruk, benar dan salah, apa yang dapat dan tidak dapat dilakukan(Sjarkawi, 2006, p. 7).

Sedangkan, agama merupakan suatu sistem kepercayaan. Menurut Gazalba yang dikutip oleh Gufron, mendefenisikan religius berasal dari kata religi dalam bahasa Latin "religio" yang akar katanya adalah religure yang artinya mengikat. Dengan demikian, religi atau 
agama mengandung arti aturan-aturan dan kewajiban-kewajiban yang harus dipatuhi dan dilaksanakan oleh pemeluknya. Monks juga berpendapat bahwa agama sebagai keterdekatan yang lebih tinggi dari manusia kepada Yang Maha Kuasa yang memberikan perasaan aman. Sementara Shihab mengatakan bahwa agama adalah hubungan antara makhluk dengan Khalik (Tuhan) yang berwujud ibadah yang dilakukan dalam sikap keseharian (Ghufron, 2010, p. 40).

Dari beberapa pengertian di atas dapat disimpulkan bahwa perkembangan agama dan moral adalah suatu kesadaran yang dimiliki oleh semua orang termasuk anak usia dini tentang baik tidaknya suatu tindakan yang dilakukan dalam menghayati hubungannya dengan sang Khalik (Tuhan). Pendapat ini juga didukung oleh penelitian terlebih dulu yang ditulis oleh Siti Nurjannah dalam penelitiannya yang berjudul Perkembangan Nilai Agama dan Moral (STTPA TERCAPAI) dari penelitian ini ia menyimpulkan bahwa perkembangan nilai agama dan moral adalah perubahan psikis yang dialami oleh anak usia dini terkait dengan kemampuannya dalam memahami dan melakukan perilaku yang baik serta memahami dan menghindari perilaku yang buruk berdasarkan ajaran agama yang diyakini.

Penilaian perkembangan pada anak usia dini pada dasarnya lebih tepat disebut dengan istilah asesmen perkembangan AUD. (Jamaris, 2006, p. 164) menjelaskan bahwa asesmen pendidikan anak usia dini adalah suatu proses kegiatan yang dilaksanakan dengan tujuan untuk mengungumpulkan data-data tentang anak mengenai perkembangan dan hasil dari kegiatan belajar yang menunjukkan sejauh mana perkembangan anak. Sedangkan menurut purwanto dalam (Yuliani, 2009, p. 2) menjelaskan bahwa kegiatan penilaian merupakan suatu proses perencanaan, memperoleh data dan menyediakan informasi yang diperlukan untuk membuat alternatif-alternatif untuk mengambil keputusan.

Menurut penelitian sebelumnya yang ditulis oleh Suyadi dengan judul penelitian "Perencanaan dan Asesmen Perkembangan Pada Anak Usia Dini (Studi kasus pada Lembaga Pendidikan Anak Usia Dini (PAUD/TK/RA) di Daerah Istimewa Yogyakarta)" Dalam dunia pendidikan asesmen diartikan dengan sebagai sebuah proses yang dilakukan secara sistematis tentang pengumpulan, penganalisisan, penafsiran, dan pemberian keputusan tentang informasi yang telah dikumpulkan. Pengertian tersebut memiliki arti bahwa asesmen bukanlah suatu hasil, melainkan suatu proses yang dilakukan secara sistematis. Di TK Al-Fadlillah Sleman, DIY guru melakukan penilaian dengan tahapan dan urutan yang telah direncenakan, dimulai dari penilaian yang dilakukan harian, mingguan, bulanan, dan terakhir penilaian semester yang dimasukkan dalam buku rapor 
yang isinya berupa seluruh pekembangan anak selama satu semester yang mencakup enam aspek perkembangan, yang salah satunya adalah aspek nilai agama dan moral.

Proses yang terdapat dalam asesmen merupakan proses yang berkelanjutan. Kegiatan asesmen bukan hal yang dilakukan diakhir kegiatan, tetapi merupakan hal yang cukup penting adalah membuat informasi dari hasil asesmen menjadi lebih bermanfaat bagi semua pihak yang berkepentingan. Pernyataan ini didukung oleh Brondinsky dalam (Decker dan Decker, 2002, p. 64) bahwa pelaporan adalah aspek penting dari program anak usia dini yang juga melibatkan orang tua agar mereka menjadi lebih bertanggung jawab terhadap perkembangan anaknya. Pelaporan ini dapat berbentuk narasi dan bukan sekedar ceklis atau angka-angka yang tanpa keterangan lebih rinci. Sebagai kesimpulan, asesmen perkembangan anak usia dini adalah sebuah proses yang dilakukan secara sistematis meliputi pengumpulan, penganalisisan, penafsiran, dan memberikan keputusan mengenai pencapaian perkembangan anak usia dini. Asesmen dilakukan untuk mengetahui hasil dari kegiatan yang dilakukan selama pembelajaran satu semester(Suyadi, 2016, p. 70).

Di TK Al-Fadlillah sleman, DIY penilaian telah dilakukan sesuai dengan perencanaan yang dibuat. Hasil dari laporan semester anak akan diberikan kepada orang tua, anak yang memiliki masalah atau belum mencapai tahap perkembangan yang ditetapkan di STPPA maka guru akan membicarakannya dengan orang tua murid secara lebih mendalam untuk mecari jalan keluar dari masalah tersebut. Terkhususnya perkembangan nilai agama dan moral yang berdampak langsung kepada tingkah laku anak dikehidupan sehari-hari maka diperlukan penanganan khusus, orang tua dan guru harus mengevaluasi kembali untuk mengetahui penyebab dari hal tersebut untuk mengetahui langkah selanjutnya yang harus diambil.

Pengembangan nilai agama dan moral anak usia dini sangat penting dilakukan agar terbentuknya perilaku yang baik dan sesuai dengan nilai-nilai yang berlaku. Pembentukan perilaku pada anak, khususnya pada anak usia dini memerlukan perhatian serta pemahaman terhadap dasar-dasar serta berbagai kondisi yang mempengaruhi dan menentukan perilaku yang berkarakter. Ada tiga strategi dalam pembentukan perilaku yang sesuai dengan nilai agama dan moral pada anak usia dini yaitu: strategi latihan dan pembiasaan, strategi aktivitas bermain, strategi pembelajaran (Suyadi, 2009, p. 109). Dari ketiga strategi yang digunakan tersebut asesmen dapat dilakukan dengan berbagai teknik salah satunya teknik penugasan berupa unjuk kerja, seperti yang dilakukan di TK Al-Fadlillah salah satu teknik yang digunakan adalah teknik penugasan (unjuk kerja). 
Hakikat penilaian pendidikan anak usia dini dilandasi oleh berbagai pandangan baik landasan psikologis, didaktif pedagogis maupun landasan administratif, yang dilihat dari sisi peserta didik dan guru (Mulyasa, 2012, p. 196). Maka dari itu untuk dapat melakukan asesmen perkembangan, khususnya perkembangan nilai agama dan moral pada anak usia dini, guru harus mengetahui standar tingkat pencapaian (STPPA) dan indikator perkembangan nilai agama dan moral sesuai dengan tingkatan usia anak, agar asesmen yang dilakukan oleh guru sesuai dengan tahapan perkembangan anak. Dikarenakan peneliti melihat asesmen aspek perkembangan nilai agama dan moral menggunakan teknik penugasan (unjuk kerja), maka adapun tingkat pencapaian perkembangan nilai agama dan moral anak usia 5-6 tahun adalah sebagai berikut:

\begin{tabular}{|c|c|c|}
\hline No & Usia anak & Tingkatan Pencapaian Perkembangan \\
\hline \multirow{6}{*}{1} & \multirow{6}{*}{$5-6$ tahun } & 1. Mengenal agama yang dianut \\
\hline & & 2. Mengerjakan ibadah \\
\hline & & 3. Berperilaku jujur, penolong, sopan, hormat, sportif, dsb. \\
\hline & & 4. Menjaga kebersihan diri dan lingkungan \\
\hline & & 5. Mengetahui hari besar agama \\
\hline & & 6. Menghormati (toleransi) agama orang lain \\
\hline
\end{tabular}

Sumber: Undang-undang Peraturan Menteri Pendidikan dan Kebudayaan Republik Indonesia No 137, Tabun 2014, Tentang Standart Nasional Pendidikan Anak Usia Dini

Melalui standar tingkat pencapaian perkembangan (STPPA) yang ada, maka guru dapat berpatokan dalam merancang pembelajan, proses dari pembelajaran, sampai penilaian dari pembelajaran yang bertunjuan mengembangkan dan melihat aspek-aspek perkembangan anak usia dini yang salah satu aspeknya adalah nilai agama dan moral. Di TK Al-Fadlillah guru telah menggunakan K13 yang semua kegiatan disekolah berpatokan dari STPPA yang ada.

KI yang menjadiacuanpenilaianperkembangan nilai agama dan moral pada anak adalah KI-1 tentang sikap spiritual yakni menerima ajaran agama yang dianutnya. Sementara kompetensi dasar yang dikembangkan dari KI tersebut antara lain mempercayai tuhan melalui ciptaanya dan menghargai diri sendiri, orang lain, dan lingkungan sekitar sebagai rasa syukur kepada Tuhan(Mulyasa, 2012, p. 5-6).

Teknik penilaian yang digunakan di TK Al-Fadlillah ada beberapa, diantaranya ada observasi, hasil karya, catatan anekdot, percakapan, pemberian tugas, demua teknik penilaian ini 
digunakan untuk melihat seluruh aspek perkembangan anak, guru menyesuaikan dengan indikator yang ingin dicapai dan kegiatan yang sedang berlangsung. Tetapi disini peneliti memfokuskan pada teknik pemberian tugas, pemberian tugas yang dipilih adalah unjuk kerja untuk melihat perkembangan nilai agama dan moral anak.

Hasil pengamatan dan wawancara secara mendalam dengan guru dan kepala sekolah yang dilakukan dilapangan, berkaitan dengan waktu pelaksanaan penilaian perkembangan nilai agama dan moral di TK Al-Fadlillah Sleman, DIY dilakukan melalui beberapa tahapan yakni penilaian harian, mingguan, penilaian bulanan, dan penilaian akhir atau penilaian semester. Penilaian harian dilaksanakan setiap hari mulai dari anak berangkat sekolah sampai anak pulang dari sekolah, penilaian dilakukan baik anak sedang melakukan kegiatan pembelajaran ataupun sedang bermain diluar kelas. Sementara penilaian mingguan merupakan rangkuman dari penilaian harian dan biasanya dan berupa hasil penilaian satu sub tema yang diajarkan dalam satu minggu tersebut, misalnya hasil penilaian dari pada subtema “ciptaan Allah". Penilaian bulanan merupakan rangkuman dari penilaian mingguan yang dilakukan setiap akhir bulan. Dan terakhir adalah penilaian semester yang dilakukan pada akhir semester. Setelah itu guru membuat laporan semester untuk diberikan kepada orang tua atau wali anak.

Teknik penilaian pemberian tugas dari jurnal Khoirul Bariyyah dengan judul penelitian “Asesmen Perkembangan Moral Agama AUD: Studi di TK ABA Pajangan Berbah Sleman", dikatakan bahwa pemberian tugas adalah satu penilaian yang dilakukan dengan memberikan tugas-tugas tertentu sesuai dengan kemampuan yang akan diungkap. Di TK Al-Fadlillah Sleman, DIY teknik penilaian penugasan yang berupa unjuk kerja rutin digunakan. Dari hasil pengamatan dan wawancara dengan guru dapat diketahui bahwa, di TK Al-Fadlillah untuk melihat aspek perkembangan nilai agama dan moral lebih sering menggunakan unjuk kerja, seperti pada penilaian harian guru setiap hari meminta anak untuk membaca doa dan surah-surah pendek yang sudah ditentukan, anak setiap hari menyalami guru sebelum masuk kelas dan sebelum pulang, di jam istirahat makan siang, guru akan mengajarkan anak-anak untuk berbagi, seluruh kegiatan tersebut dapat dinilai dengan teknik penugasan berupa pemberian tugas. Pada kegiatan mingguan kegiatan yang dinilai menggunakan teknik penugasan (unjuk kerja) antara lain, praktek beribadah yang lebih kompleks yang tidak dilakukan setiap hari di kelas seperti mempraktekkan gerakan sholat, gerakan berwudu dan lain sebagainya. Sedangkan penilaian bulan adalah hasil gabungan dari penilaian mungguan yang dijadikan satu, begitupun penilaian semester yang merupakan hasil 
penilaian secara keseluruhan, walaupun guru tetap menggunakan teknik penilaian yang lain agar semua aspek perkembangan anak dapat diketahui secara lebih jelas, tepat, dan akurat.

Teknik penilaian yang penulis dapat di TK Al-Fadillah kelompok B usia 5-6 tahun pada saat observasi penulis akan memaparkan penilaian hasil karya dalam asesmen yang keterkaitannya dengan aspek pengetahuan dari teknik penilaian hasil karya penulis dapat melihat bahwasannya anak sudah mampu berkembang sesuai yang diharapkan karena dari hasil karya yang anak kerjakan anak mulai dilatih untuk mengenal kegiatan dalam kegiatan anak sehari-hari sesuai dengan KD Permendikbud No. 146 tahun 2014 yang guru masukan dari indikator perkembangannya. Dan dari hasil karya tersebut anak mulai memahami bahwasannya semua benda itu ciptaan tuhan, dan motorik halus anak akan berkembang sangat baik ketika anak menebalkan gambar sesuai dengan instruksi guru. dan dalam teknik penilaian guru akan melihat secara langsung, jadi apa kegiatan yang sedang anak lakukan dan anak selesai dalam mengerjakan tugas tersebut guru akan melihat melalui hasil pengamatan guru dan apakah anak memahami dan berkembang sesuai yang diharapkan atau butuh dukungan dan latihan untuk melihat perkembangan anak tersebut.

Teknik penilaian dari Jurnal dari Rohita dan Nurfadilah dengan Judul penelitian "Pelaksanaan Penilaian Pembelajaran di Taman Kanak-Kanak (Studi Deskriptif pada Taman Kanak-Kanak di Jakarta)". Di dalam melakukan asesmen semua teknik penilaian digunakan untuk mencakup semua aspek perkembangan anak usia dini secara lebih akurat, termasuk di dalamnya penilaian dengan menggunakan tes. Berbeda dengan TK AlFadlillah Sleman, DIY dari wawancara dengan salah satu guru menjelaskan bahwa di sekolah ini tidak menggunakan teknik penilaian tes, dikarenakan kurang tepat untuk anak, karena di PAUD asesmen tidak melihat hasil melainkan proses dari awal sampai akhir. Pendapat ini Sesuai dengan penelitian sebelumnya yang dilakukan oleh Khoirul Bariyyah dengan judul penelitian “Asesmen Perkembangan Moral Agama AUD: Studi di TK ABA Pajangan Berbah Sleman", yang mengatakan bahwa dalam pembelajaran di PAUD asesmen tidak digunakan untuk menentukan hasil seorang anak dalam mengikuti pembelajaran, tetapi digunakan untuk mengukur tingkat pencapaian perkembangan pada setiap anak. Maka dari itu di TK Al-Fadlillah guru tidak menggunakan teknik penilaian tes.

Dari penilaian menggunakan teknik pemberian tugas (unjuk kerja) guru dapat melihat beberapa aspek di dalam perkembangan nilai agama dan moral diantaranya: aspek pemahaman dan hafal (anak dapat mengingat gerakan sholat dan berwudhu secara benar, anak dapat menghafal doa sehari-hari dan ayat-ayat pendek yang sudah sering diajarkan), 
aspek berani (anak berani maju kedepan untuk mempraktekkan apa yang diminta oleh guru), aspek kerja sama (anak dapat melakukan kegiatan yang dituntut berkelompok secara baik). Dari data yang di peroleh dari lapangan diketahui bahwa anak-anak di TK Al-Fadlillah perkembangan nilai agama dan moral sudah di atas rata-rata, hasil ini dilihat dari penilaian sebelumnya yang sudah diambil oleh guru dan dari rapor anak semester sebelumnya. Selain dari data tersebut dilapangan peneliti juga melihat secara langsung pembelajaran dan bagaimana perkembangan anak yang tampak. Anak tahu agama yang dianutnya, Anak sudah dapat membaca doa dan surah-surah pendek, ketika diminta mempraktekkan gerakan sholat anak sudah bisa, hanya beberapa anak yang belum hafal sampai habis gerakan. Anak-anak ketika makan selalu berbagi dengan temannya, mau menyalami guru. Dari beberapa kegiatan yang mencakup aspek nilai agama dan moral guru melakukan penilaian menggunakan unjuk kerja dan dibantu oleh teknik penilaian-penilaian yang lain.

\section{KESIMPULAN}

Asesmen merupakan hal yang sangat penting untuk dilakukan di PAUD, asesmen dilakukan untuk mengetahui pegaimana tingkat pencapaian perkembangan anak, sehingga ketika ada anak yang belum berkembang sesuai dengan tahapannya guru segera tahu dan dapat membicarakannya dengan orang tua/wali dari anak untuk menanggulangi hal tersebut, asesmen juga digunakan untuk mengetahui bagaimana hasil dari kegiatan yang dilakukan selama satu semester sehingga guru dapat melakukan evaluasi. Asesmen dilakukan untuk melihat enam aspek perkembangan dalam diri anak, salah satu aspek perkembangan yang sangat penting adalah aspek nilai agama dan moral, dimana aspek ini akan menjadi penyambung hubungannya dengan Tuhan, orang sekitar, dan seluruh makhluk ciptaan Allah. Penanaman nilai agama dan moral pada usia dini diharapkan mampu untuk menjadikan anak memiliki nilai-nilai yang baik sesuai dengan ajaran agama dan karakter yang baik pula.

Teknik penilaian yang di gunakan di PAUD sangatlah beragam, guru dapat menyesuaikan dengan aspek yang ingin dicapai dengan kegiatan atau situasi dan kondisi yang sedang berlangsung. Pada aspek nilai agama dan moral di TK Al-Fadlillah menggunakan beberapa teknik penilaian diantaranya tanya jawab, observasi, hasil karya, catatan anekdot, dan pemberian tugas. Teknik penilaian yang paling sering digunakan dalam melihat perkembangan nilai agama dan moral adalah pemberian tugas, pemberian tugas yang dimaksud disini adalah berupa unjuk kerja. Melalui unjuk kerja guru dapat menilai banyak aspek mulai dari anak memahami, anak hafal, anak berani, dan dapat bekerja sama. 


\section{REFERENSI}

Ai Sulastri. (2014). Pentingnya Pendidikan Anak Usia Dini di Indonesia. Garut: tp.

Anik Lestariningrum. (2014). "Pengaruh Penggunaan Media VCD Terhadap Nilai-Nilai Agama dan Moral Anak". Jurnal Pendidikan Usia Dini. Vol. 8. No. 2.

Anita Yus. (2012). Penilaian Perkembangan Belajar Anak. Taman Kanak-kanak. Jakarta: Kencana.

Emzir. (2011). Metodologi Penelitian Kualitatif: Analisis Data Ke-2. Jakarta Utara: Raja Grafindo Persada.

H. E. Mulyasa. (2012). Managemen PAUD. Bandung: Remaja Rosdakarya.

Khoirul Bariyyah. (2016). "Asesmen Perkembangan Moral Agama pada AUD”. Jurnal Pendidikan Anak. Vol. 2. No. 1.

Lara Fridani. (2008). Evaluasi Perkembangan Anak Usia Dini. Jakarta: Universitas Terbuka.

Martini Jamaris. (2006). Perkembangan dan Pengembangan Anak Usia Taman Kanak-kanak. Jakarta: Gramedia.

N. M. Gufron dan Risnawita. (2010). Teori-teori Psikologi. Yogyakarta: Ar-Ruzz Media.

NS. Yuliani. (2013). Asesmen Perkembangan Anak Berbasis Kecerdasan Jamak. Bandung.

Rohita, \& Nurfadilah, (2017). "Pelaksanaan Penilaian Pembelajaran di Taman Kanak-Kanak (Studi Deskripif pada Taman Kanak-Kanak di Jakarta)". Jurnal Al-Az̧ar Indonesia Seri Humaniroh. Vol. 4. No.1.

Siti Nurjannah. (2018). "Perkembangan Nilai Agama dan Moral (STPPA Tercapai)". Jurnal Paramurobi. Vol. 1. No. 1.

Sjarkawi. (2006). Pembentukan Kepribadian Anak : Peran Moral, Intelektual, Emosional, dan Sosial sebagai Wujud Integritas Membangun Jati Diri. Jakarta: Bumi Aksara.

Sugiyono. (2014). Metode Penelitian Kuantitatif, Kualitatif, dan R\&D. Bandung: Alfabeta.

Suyadi. "Perencanaan dan Asesmen Perkembangan pada Anak Usia Dini". Jurnal Ilmiah Tumbuh Kembang Anak. Usia Dini. Vol. 1. No. 1.

Zurqoni. (2013). Menakar Akhlak Siswa: Konsep dan Strategi Penilaian Akhlak Mulia Siswa.

Yogyakarta: Ar-Ruzz Media. 